\title{
Transient Wheal Attack Corresponding to the Tumor Lesions of Primary Cutaneous Diffuse Large B Cell Lymphoma, Leg Type after Successive Rituximab Treatment
}

\author{
Saori Itoi Atsushi Tanemura Misa Hayashi Naoko Nagata \\ Mamori Tani Ichiro Katayama \\ Division of Dermatology, Department of Integrated Medicine, Osaka University Graduate \\ School of Medicine, Osaka, Japan
}

\section{Key Words}

B cell lymphoma $\cdot$ Leg type $\cdot$ Rituximab $\cdot$ Wheal $\cdot$ Successful treatment

\begin{abstract}
An elderly male noticed urticarial patches corresponding to cutaneous B cell lymphoma lesions after rituximab treatment. Along with the resolution of urticaria, the lymphoma lesions completely remitted without recurrence. In this communication, we present an interesting case and the pathophysiological findings of a wheal attack in a case with tumor remission following systemic treatment with rituximab, a monoclonal anti-CD20 antibody.
\end{abstract}

(c) 2014 S. Karger AG, Basel

\section{Introduction}

The distinct subset of primary cutaneous diffuse large B cell lymphoma, leg type (PCDLBCL-LT) is characterized by frequent recurrence, extracutaneous dissemination and a high mortality rate [1]. To improve patients' outcome a monoclonal antibody, rituximab, directed against the B cell antigen CD20, was recently approved for the treatment of B cell lymphomas [2].

In the present case, a wheal attack developed particularly at the site of tumor lesions, and those tumor lesions subsequently disappeared after rituximab monotherapy. Only a few 
Itoi et al.: Transient Wheal Attack Corresponding to the Tumor Lesions of PCDLBCL-LT after Successive Rituximab Treatment

cases of rituximab-related urticarial reactions have been reported in patients treated for B cell lymphoma [3-6]. Therefore, we would like to report a rare case and discuss the possible mechanism underlying rituximab-related urticarial reaction, which may improve the understanding of an unrecognized clinical effect of rituximab on tumors.

\section{Case Report}

A 73-year-old male presented to our department in January 2010 with a 7-year history of erythematous skin patches on his left lower leg which had not improved after the use of topical steroids. At initial physical examination, erythema and red-to-brown-colored, various-sized cutaneous nodules were found on the bilateral lower legs (fig. 1a). Histological study showed dense infiltration of lymphoid cells with irregular nuclei in the superficial and deep dermis (fig. 1b, c), and immunohistological staining revealed that most of the infiltrating lymphoid cells were positive for CD20 (fig. 1d). The patient had no fever, weight loss or night sweats. Whole body imaging studies and bone marrow histopathology did not detect metastatic or disseminated disease. Based on these results, we diagnosed the patient with PCDLBCL-LT, which was stage IB according to the WHO-EORTC classification.

Based upon the standard chemotherapy regimen, we administered biweekly combination chemotherapy with rituximab, pirarubicin, cyclophosphamide, vincristine and prednisolone (R-THP-COP). Within $2 \mathrm{~h}$ after the initial administration of intravenous rituximab, he noticed urticaria along the tumor lesions (fig. 1e), and these urticarial lesions disappeared rapidly following treatment with an oral antihistamine. Four weeks after the second course of R-THP-COP chemotherapy, the tumor lesions had completely remitted (fig. 1f), which was confirmed by no evidence of CD20-positive lymphoid tumor cells in his skin (fig. 1g). He has remained in remission for 5 years under clinical observation.

\section{Discussion and Conclusions}

We experienced a rare case with a wheal attack that developed on the sites of PCDLBCL-LT tumor lesions after the induction of rituximab therapy. Rituximab is a chimeric monoclonal antibody consisting of the variable region of murine anti-CD20 and the human IgG1(K) heavy and light chain constant regions, and is known to successfully treat patients with CD20-positive indolent and aggressive B cell non-Hodgkin lymphomas [1]. The three main mechanisms known to underlie the anti-tumor effects of rituximab are complementmediated cytotoxicity (recruiting neutrophils through the release of chemotactic C3a and C5a fractions), antibody-dependent cell-mediated cytotoxicity (especially that mediated by natural killer cells) and/or direct cytotoxicity [7-9]. In addition, it was reported that the levels of C3, C4 and cytokines such as IL-6, IL-8 and TNF- $\alpha$ were increased within $30 \mathrm{~min}$ after the administration of rituximab in patients with low-grade non-Hodgkin's lymphoma [10]. Based on this evidence, it has been supposed that rituximab is somehow recognized by the immune system of the patient, and activation of the above three pathways might stimulate mast cells, followed by an increase in blood vessel permeability exclusively in both the urticarial and tumor lesions.

In the present case, we could not examine the complement level and mast cell infiltration on the active wheal lesions. Further accumulation of similar cases and their detailed observations would help clinicians understand the exact mechanisms underlying the development of rituximab-related wheal attacks in patients with cutaneous lymphoma. 


\begin{tabular}{l|l}
\hline DOI: $10.1159 / 000367936$ & $\begin{array}{l}\text { C 2014 S. Karger AG, Basel } \\
\text { www.karger.com/cde }\end{array}$ \\
\hline
\end{tabular}

Itoi et al.: Transient Wheal Attack Corresponding to the Tumor Lesions of PCDLBCL-LT after Successive Rituximab Treatment

\section{Disclosure Statement}

The authors report no conflict of interest.

\section{References}

1 Petryk M, Grossbard ML: Rituximab therapy of B-cell neoplasms. Clin Lymphoma 2000;1:186-194; discussion 195-196.

2 Demidem A, Lam T, Alas S, Hariharan K, Hanna N, Bonavida B: Chimeric anti-CD20 (IDEC-C2B8) monoclonal antibody sensitizes a B cell lymphoma cell line to cell killing by cytotoxic drugs. Cancer Biother Radiopharm 1997;12:177-186.

-3 Rey J, Wickenhauser S, Ivanov V, Coso D, Gastaut JA, Bouabdallah R: A case of rituximab-related urticarial reaction in cutaneous B-cell lymphoma. J Eur Acad Dermatol Venereol 2009;23:210.

-4 Errante D, Bernardi D, Bianco A, De Nardi S, Salvagno L: Rituximab-related urticarial reaction in a patient treated for primary cutaneous B-cell lymphoma. Ann Oncol 2006;17:1720-1721.

-5 Heinzerling LM, Urbanek M, Funk JO, Peker S, Bleck O, Neuber K, Burg G, von den Driesch P, Dummer R: Reduction of tumor burden and stabilization of disease by systemic therapy with anti-CD20 antibody (rituximab) in patients with primary cutaneous B-cell lymphoma. Cancer 2000;89:1835-1844.

6 Ingen-Housz-Oro S, Ortonne N, Chosidow 0: Rituximab-related urticarial reaction overlying primary cutaneous follicle centre lymphoma: histological appearance and pathophysiological hypotheses. J Eur Acad Dermatol Venereol 2014;28:976-978.

7 Weiner GJ: Rituximab: mechanism of action. Semin Hematol 2010;47:115-123.

8 Amoroso A, Hafsi S, Militello L, Russo AE, Soua Z, Mazzarino MC, Stivala F, Libra M: Understanding rituximab function and resistance: implications for tailored therapy. Front Biosci 2011;16:770-782.

-9 Reff ME, Carner K, Chambers KS, Chinn PC, Leonard JE, Raab R, Newman RA, Hanna N, Anderson DR: Depletion of B cells in vivo by a chimeric mouse human monoclonal antibody to CD20. Blood 1994;83: 435-445.

10 van der Kolk LE, Grillo-Lopez AJ, Baars JW, Hack CE, van Oers MH: Complement activation plays a key role in the side-effects of rituximab treatment. Br J Haematol 2001;115:807-811. 


\section{Case Reports in Dermatology}

\begin{tabular}{l|l}
\hline Case Rep Dermatol 2014;6:218-221 \\
\hline DOI: 10.1159/000367936 & $\begin{array}{l}\text { C 2014 S. Karger AG, Basel } \\
\text { www.karger.com/cde }\end{array}$ \\
\hline
\end{tabular}

Itoi et al.: Transient Wheal Attack Corresponding to the Tumor Lesions of PCDLBCL-LT after Successive Rituximab Treatment
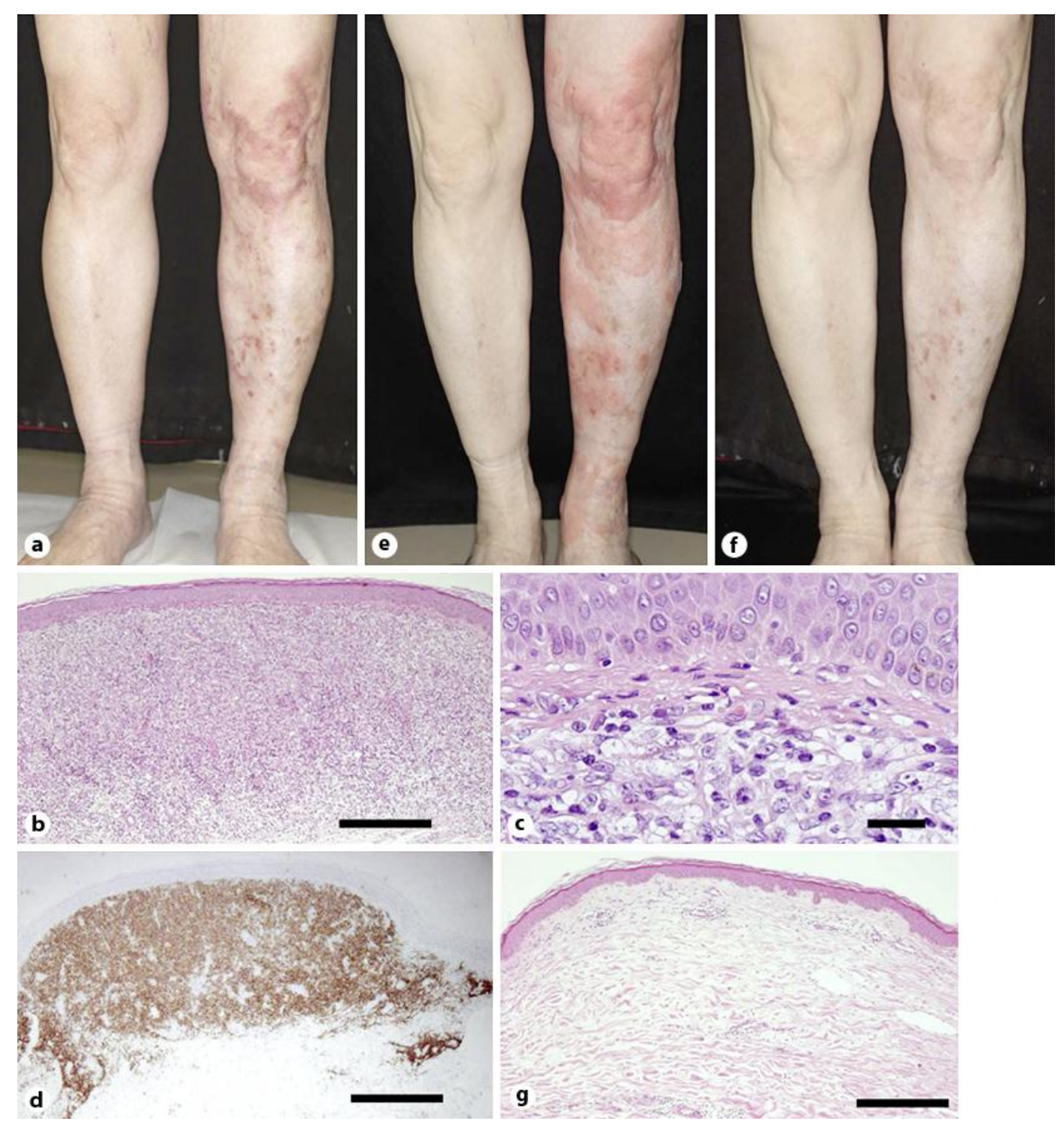

Fig. 1. a Clinical features at first hospitalization. Finger- to fist-sized indurative and erythematous plaques were noted throughout the left lower leg. b, c Histopathological features at first medical examination. Bars $=250 \mu \mathrm{m}$ (b) and $50 \mu \mathrm{m}$ (c). A grenz zone was notable, and dense infiltration of lymphoid cells with large-scaled nuclei was identified throughout the entire dermis. Most of these were centrocyte-like cells. d The infiltrated lymphoid cells were positive for CD20. Bar $=250 \mu \mathrm{m}$. e Clinical features $2 \mathrm{~h}$ after rituximab administration. $\mathbf{f}$ Clinical features of the complete remission of PCDLBCL-LT 20 days after rituximab administration. $\mathbf{g}$ Histopathological features at the time of complete remission of PCDLBCL-LT. Bar $=$ $250 \mu \mathrm{m}$. 